\title{
MESOZOIC-CENOZOIC EVOLUTION OF DIAMONDIFEROUS PROVINCE OF FRANCA, SÃO PAULO STATE, BRAZIL
}

\section{LEILA CRISTINA PERDONCINI ${ }^{1}$, NORBERTO MORALES ${ }^{2}$, ANTENOIR ZANARDO ${ }^{3}$, SEBASTIÃO GOMES DE CARVALHO $^{4}$, YOCITERU HASUI ${ }^{5}$, JOÃO BATISTA SENA COSTA ${ }^{6}$, MAURÍCIO BORGES ${ }^{7} \&$ JAIRO ROBERTO JIMENEZ RUEDA ${ }^{8}$}

\begin{abstract}
RESUMO A Província Diamantífera de Franca (SP) situa-se na porção nordeste da Bacia do Paraná, sendo margeada pelo Soerguimento do Alto Paranaíba (MG). Eventos tectono-sedimentares determinaram a história geológica da região, controlando a distribuição da sedimentação detrítica, em particular a do Grupo Bauru (Cretáceo Superior-Eoceno), da Formação Franca (Eoceno-Mioceno Médio) e das Coberturas Indiferenciadas (Mioceno Médio-Pleistoceno Superior), e a formação dos pláceres diamantíferos (Quaternário), mostrando uma sedimentação fortemente associada à elaboração de superfícies de aplanamento. Os diamantes são incolores, tipo gema, variando entre 0,10 e $0,30 \mathrm{ct} / \mathrm{pedra}$. Ocorrem como cristais tetrahexaédricos, cúbicos e octaédricos apresentando marcas de percussão. A assembléia mineralógica (calcedônia, quartzo, goethita, crisoberilo, cianita, rutilo, almandina, ágata, ilmenita, magnetita, sílex, zircão, apatita, estaurolita, limonita, basalto/diabásio, arenito, quartzito, entre outros) presente nos principais aluviôes mineralizados (rios Canoas, Santa Bárbara/Sapucaizinho e das Pedras) é compatível com aquelas dos sedimentos eocretáceos e cenozóicos. Estas características associadas a ausência de minerais kimberlíticos, além da presença de rubi, carbonados e ouro, sugerem a formação de pláceres diamantíferos por retrabalhamento sedimentar vinculada a eventos de desnudação continental, a partir da erosão de rochas kimberlíticas presentes no Soerguimento do Alto Paranaiba, adjacente, proporcionando seleção e enriquecimento progressivo de material resistato nos sedimentos eo-cretáceos (Grupo Bauru) e cenozóicos (Formação Franca e Coberturas Indiferenciadas), evoluindo para a formação de pláceres diamantíferos quaternários.
\end{abstract}

Palavras-chave: Grupo Bauru, sedimentação cenozóica, superfícies de aplainamento, pláceres diamantíferos

\begin{abstract}
The region of Franca, São Paulo State (Brazil), is located in northeastern limits of Paraná Basin, aside the Alto Paranaíba Uplift. The mesozoic-cenozoic geology of this region was conditioned by tectono-sedimentary events, wich controlled the planation surfaces developement and their detritic sedimentary distribution: Bauru Group (Upper Cretaceous-Eocene), Franca Formation (Eocene-Middle-Miocene), surface sedimentary covers (Middle Miocene-Upper Pleistocene) and the diamondiferous placeres formation (Quaternary). The diamonds occur in Santa Bárbara, Sapucaizinho, Canoas, Cascavel and Pedras rivers, where are recovered by high and low terraces, and from active stream sediments. They are colourless, tetrahexahedral, octahedral, cubic and macle showing percussion marks, and their sizes are concentrated between 0,10 to $0,30 \mathrm{ct} / \mathrm{st}$. The mineral assemblage associated are magnetite, ilmenite, limonite, goethite, quartz, kyanite, corindon, epidote, silex, zircon, tourmaline, rutile, citrine, garnet, gold, besides carbonate, bort and balla, among others, that is consistent with eo-cretaceous and cenozoic sediments. Erosion/deposition events have promoted the kimberlitic rocks erosion, provinding selection and progressive enrichment of resistent material in the eo-cretaceous (Bauru Group) and cenozoic (Franca Formation and Coberturas Indiferenciadas) sediments, coming to form quaternary diamondiferous placers.
\end{abstract}

Keywords: Bauru Group, cenozoic sedimentation, planation surfaces, diamondiferous placers.

INTRODUCTION The Diamondiferous Province of Franca, São Paulo State (Brazil), is located in northeast portion of the Paraná Basin, near the southeast border of Alto Paranaíba Uplift (Fig. 1). This province includes the basins of the Santa Bárbara and Sapucaizinho rivers (tributaries of the Sapucaí river) flowing toward SW, and the Canoas, Cascavel and Pedras rivers (tributaries of the Grande river) running toward NE and $\mathrm{N}$. These diamondiferous basins developed amphitheatres limited by escarpments controlled by regional structures, outlining the Sul-Americana Surface in the Paraná Basin, in whose plateaux and mountains their springs are distributed. Diamonds are recovered from high terraces, low terraces and from active stream sediments.

GEOLOGIC SETTING The area is characterised by meta- morphic rocks of the Araxá Group (Precambrian) overlain unconformably by glaciogenic sediments of the Aquidauana Formation (Permo-Carboniferous) and fluvial-eolic sandstones of the Botucatu Formation, and intruded by the Borda da Mata diabase sill (Triassic-Cretaceous). Basalts of the Serra Geral Formation (Triassic-Cretaceous), distributed over the Botucatu sediments, support the plateaux, mountains and hills and are overlain by the Bauru Group siliciclastic rocks (CretaceousEocenozoic). All these lithological units are covered by lateritizated eluvial-coluvial sediments (Franca Formation, Cenozoic).

MINERAL ASSEMBLAGE The diamond crystals are octahedral or octahedral/tetrahexahedral combination varieties, amorphous and macle crystals. Carbonado and balla occur
I leilacp@ms.rc.unesp.br

2 nmorales@rc.unesp.br

3 azanardo@rc.unesp.br

4 carvalho@rc.unesp.br
5 hasui@terra.com.br

6 jbsenacosta@ufpa.br

mborges@ufpa.br

rjr@ms.rc.unesp.br 


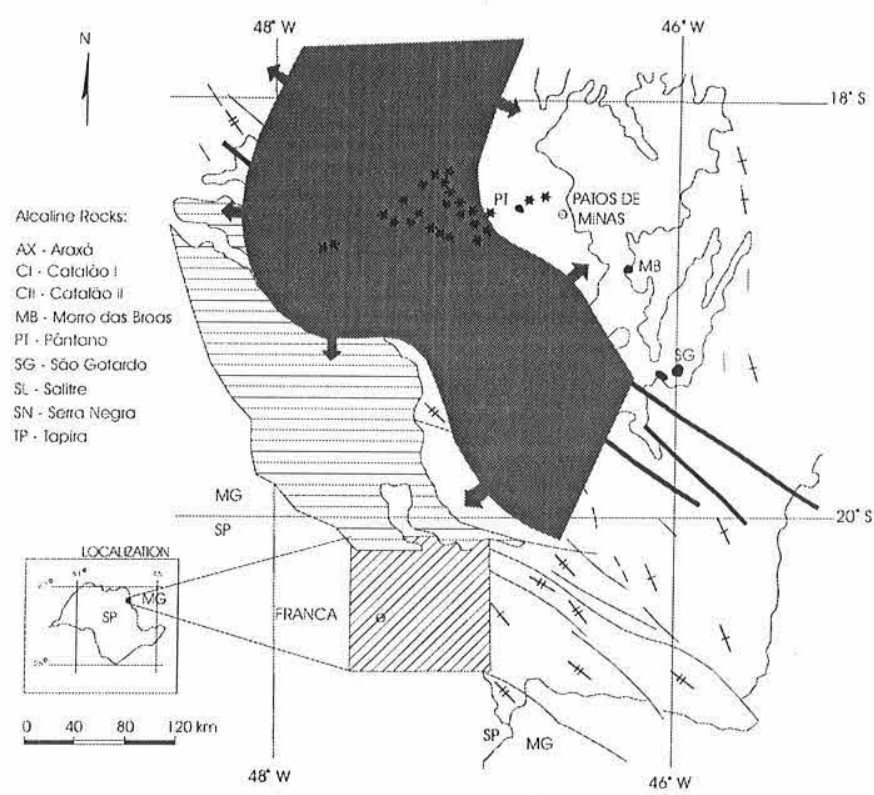

Modlled from Arnelda, (1986).
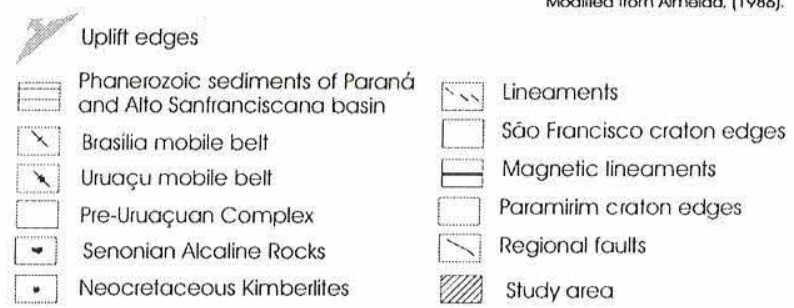

Figure 1.Diamondiferous Franca Province location, Alto Paranaiba Uplift and their kimberlitic rocks distribution, and sedimentary basin associated. Modified from Almeida (1986).

associated. The diamonds are colourless to yellow, with rare brown and green stones and their sizes cluster around 0,10 to $0,30 \mathrm{ct} / \mathrm{st}$, with occasionaly bigger stones (80 ct/st) (Fig. 2).

The mineral assemblage associated with diamond placers comprises magnetite, ilmenite, limonite, goethite, quartz, anatase, kyanite, ruby, sapphire, chalcedony, crisoberile, epidote, silex, zircon, tourmaline, rutile, citrine, garnet and gold, among others (Fig. 2). However, indicators of proximal diamond primary sources were not found.

GEOLOGIC EVOLUTION After the alkaline/kimberlitic rocks were emplaced along the Alto Paranaíba Uplift (NW-SE) and sedimentation ended in the Alto Sanfranciscana and Paraná basins (Almeida, 1983; Almeida, 1986; and Hasui; Haralyi, 1991), intense denudation events occurred producing planation surfaces and sedimentary covers (Gondwana Surface; Sul-Americana Surface, Velhas cycle; Paraguaçu cycle) (King, 1956; Bigarella; Andrade, 1965; Braun, 1971; IPT, 1981; Ponçano; Almeida, 1993; Valadão, 1998, among others). These events generated thick sedimentary sequences, from the Cretaceous to the Quaternary, determining the detrital sediment distribution/concentration in the Franca region (Fig. 3).

Four phases of erosion/deposition promoted the selection, dispersion and progressive enrichment of diamonds in the
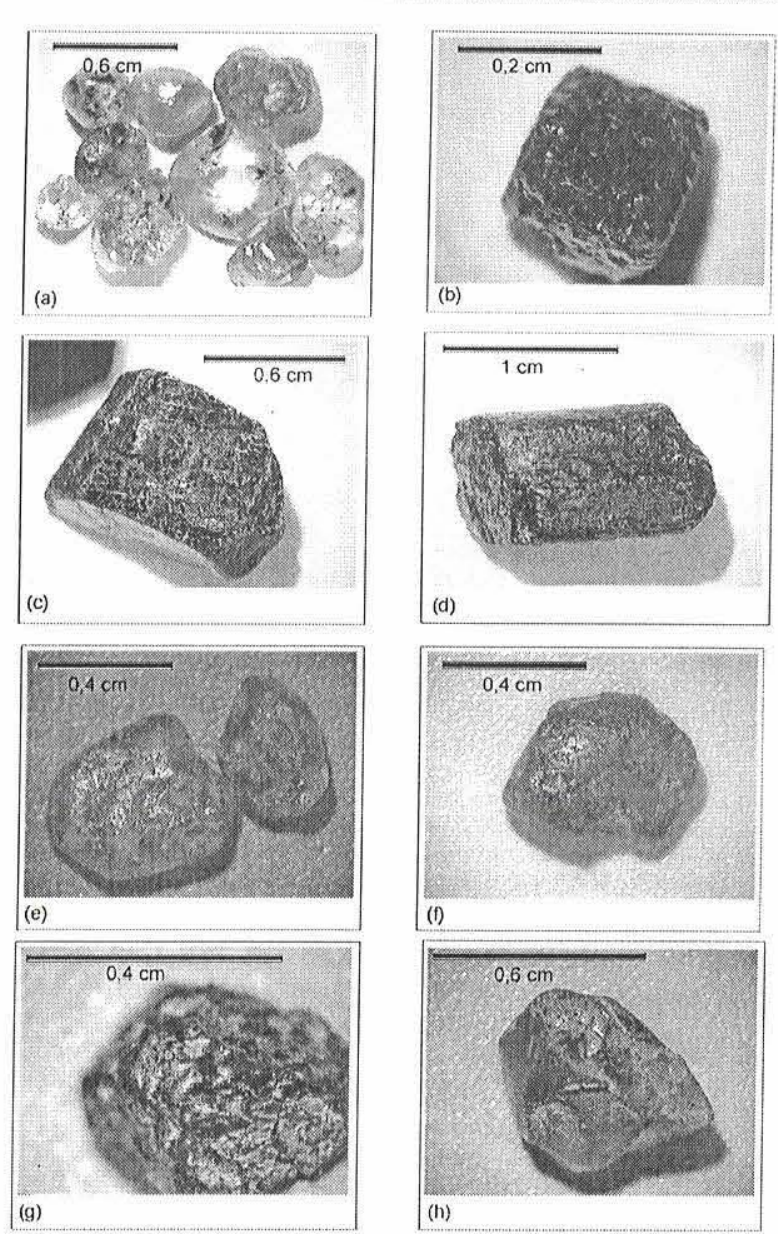

Figure 2. Diamonds and some associated heavy minerals from the Franca Province: (a) Eight diamond crystals flat tetrahexahedroid/octaedron combination and one cube, colorless to yellow, around 0,10 ct/st. (b) Indented cube with subordinate tetrahexaedroid form. (c) Subhedral ilmenite. (d) Subhedral rutile. (e) Ruby with polished surfaces. (f) Sapphire with polished surfaces. (g) Garnet with preserved surfaces. (h) Corindon with polished surfaces.

cretaceous and cenozoic sediments. They are characterised by pulses of sedimentation that concentrated diamonds from Alto Paranaíba kimberlites, in the Franca region.

Phase 1: erosion of the Alto Paranaíba diamond primary sources, associated to the establishment of the Post-Gondwna Surface, generated the diamondiferous gravels of the Bauru Group in the Franca region, SP (Ponçano et al., 1992) and Uberaba Formation in the Triângulo Mineiro, MG (Late Cretaceous-Eocene) (Hasui, 1967; Hasui and Haralyi, 1991; Santos et al., 1994; Hasui et al., 1999), figs. 3a, 3b, 3c. It's tractive deposits could have concentrated diamonds.

Phase 2: erosion of the mineralised Bauru Group (and Uberaba Formation) and of the Alto Paranaíba primary sources generated cenozoic sedimentary deposits associated with the Sul-Americana Surface (Late Cretaceous-Middle Miocene) 


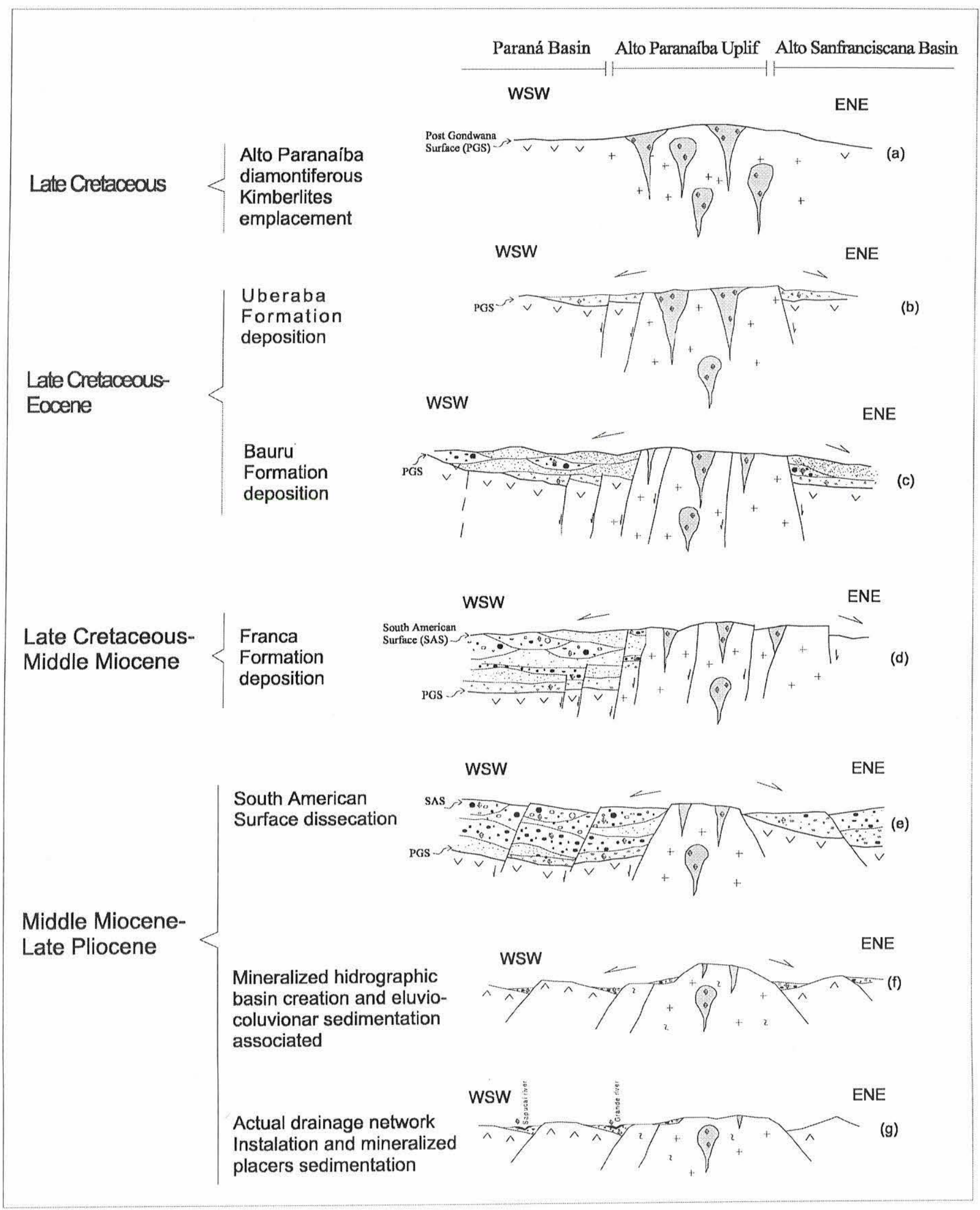

Figure 3. Mesozoic-Cenozoic Evolution of Diamondiferous Province of Franca, São Paulo State, Brasil. 
(King, 1956; Braun, 1971; Ponçano; Almeida, 1991; Valadão, 1998) which is distributed between 1000-1280m; fig. 3d. Detritical fluxes dispersed their sediments around an extended area.

Phase 3: dissection of the Sul-Americana Surface (Velhas cycle, King, 1956) originated the mineralised basins. Their sediments occupy an intermediate position (700-800 m), the Neogênica surface (De Martonne, 1943) or Sul-Americana I Surface (Valadão, 1998) situated between the Sul-Americana surface $(1000-1280 \mathrm{~m})$ and the Grande and Sapucaí rivers valleys ( $600 \mathrm{~m})$ (Middle Miocene-Late Pliocene); figs. 3e, $3 \mathrm{f}$. Diamond-bearing sediments (Bauru Group and Franca Formation) were ressedimented by detritical fluxes and tractive sedimentation, around four portions of Franca region, limited by escarpments.
Phase 4: erosion of the diamond-bearing units formed during the previous phases, resulted in the deposition of quaternary placers, which have been concentrating diamonds since the installation of the current drainage network (PleistoceneHolocene); fig. $3 \mathrm{~g}$.

CONCLUSION The diamonds characteristics, their distribution and different origins, together with the apparent absence of kimberlitic minerals reflect long and multi-cyclic sedimentary transport. These facts, in addition to the different erosive-depositional events, in the Franca region, show the strong tectono-sedimentary mineralization control acting in the Sul-Americana plate during the Mesozoic-Cenozoic.

Acknowledgements To CNPq (Process 570113/97-0) and FAPESP (Process 95/4417-3) for financial support.

\section{References}

ALMEIDA, F. F. M., 1983. Relações tectônicas das rochas alcalinas mesozóicas da regiāo meridional da plataforma Sul-Americana. Revista Brasileira de Geociências, São Paulo, v. 13, n. 3, p. 139-58,1983.

ALMEIDA, F. F. M., 1986. Distribuição regional e relações tectônicas do magmatismo pós-Paleozóico no Brasil. Revista Brasileira de Geociências, São Paulo, v. 16, n. 4, p. 325-349, 1986.

BARCELOS, J. H., 1984. Reconstrução paleogeográfica da sedimentação do Grupo Bauru baseada na sua redefinição estratigráfica parcial em território paulista e no estudo preliminar fora do Estado de São Paulo. São Paulo, 1984. Tese (Livre Docência). Instituto de Geociências, Universidade Estadual Paulista.

BARCELOS, J. H., et al. 1983. Formação Itaqueri: um exemplo de tectofácies. In: SIMPÓSIO REGIONAL DE GEOLOGIA, 4., 1983. Atas...SBG, p. 245-252.

BIGARELLA, J.J.; ANDRADE, G. O., 1965. Contribution to the study of the Brazilian Quaternary. Geol. Soc. Am. International Studies on the Quaternary, S.I.P., Special Paper, v.84, p. 333-45I, 1965.

BRAUN, O. P. G., 1971. Contribuição à geomorfologia do Brasil Central. Revista Brasileira de Geografia, Rio de Janeiro, v. 3, n. 32, p. 3-39, 1971.

DE MARTONNE, E., 1943. Problemas morfológicos do Brasil tropical atlântico. Revista Brasileira de Geografia, Rio de Janeiro, v. 5, n. 4, p. 523-550, 1943.

FÚLFARO, V. J.; SUGUIO, K., 1974. O Cenozóico paulista: gênese e idade. In: CONGRESSO BRASILEIRO DE GEOLOGIA, 28., 1974. Porto Alegre. Anais...Porto Alegre. SBG, 1974. p. 91-101.

FÚLFARO, V. J., et al., 1994. A margem goiana do Grupo Bauru: implicaçōes na litoestratigrafia e paleogeografia. In: SIMPÓSIO SOBRE O CRETÁCEO DO BRASIL, 3., 1994, Rio Claro. Boletim...Rio Claro, 1994. p. 81-84.

HASUI, Y., 1967. Geologia das formações cretáceas do oeste de Minas Gerais. São Paulo; 1967. 80 f. Tese (Doutorado). Escola Politécnica, Universida- de de São Paulo.

HASUI, Y.; HARALYI, N., 1991. Aspectos lito-estruturais e geofísicos do soerguimento do Alto Paranaíba. Geociências, São Paulo, v. 10, p. 57-77, 1991.

INSTITUTO DE PESQUISAS TECNOLÓGICAS DO ESTADO DE SÃO PAULO - IPT, 1981. Mapa Geológico do Estado de São Paulo. São Paulo, 1981, 2v. Escala 1:500.000. (IPT, Monografias, 6).

KING, L. C., 1956. A geomorfologia do Brasil oriental. Revista Brasileira de Geografia, Rio de Janeiro, v. 18, n. 2, p. 147-265, 1956.

PERDONCINI, L. C.; SOARES, P. C. 1999. O diamante na bacia do rio Santa Rosa, Tibagi (PR). Revista Brasileira de Geociências, São Paulo, v.29, n.3, p299-306, 1999

PONCANO, W. L. et al., 1992. Avaliação preliminar do potencial diamantífero da região francana (SP). Cadernos I. G. UNICAMP, v. 2, n. I, p. 54 - 89 , 1992.

PONCCANO, W. L.; ALMEIDA, F. F. M., 1993. Superfícies erosivas nos planaltos cristalinos do leste paulista e adjascências: uma revisão. Cadernos I. G UNICAMP, v. 3, n. 1. p. 55-90, 1993

SANTOS, M. C., et al., 1994. Estudo preliminar da faciologia do Membro Serra da Galga, Formação Marília do Grupo Bauru a noroeste de Uberaba, Triângulo Mineiro, MG. In: CONGRESSO BRASILEIRO DE GEOLOGIA, 38., 1994, Balneário Camboriú, SC. Resumo expandido...Balneário Camboriú: SBG, 1994. p. 262-264.

VALADÃO, R. C., 1998. Evolução de longo-termo do relevo do Brasil oriental (desnudação, superfícies de aplanamento e soerguimentos crustais). Salvador, 1998. 243 f. Tese (Doutorado). Universidade Federal da Bahia.

Manuscrito NB-041

Recebido em 28 de novembro de 2001 Revisão dos autores em 29 de dezembro de 2001 Revisão accita em 30 de dezembro de 200 